\title{
ANALISIS KERAGAMAN GENETIK TIGA STRAIN \\ NILA MERAH (Oreochromis sp) DENGAN ANOVA RAPD
}

\author{
Iskandariah $^{1 *}$, Otong Zenal Arifin ${ }^{1}$ dan Rudhy Gustiano ${ }^{2}$ \\ ${ }^{1}$ Balai Riset Perikanan Budidaya Air Tawar \\ Jl. Sempur No.1, Bogor \\ *e-mail : iskandariah.3010@gmail.com \\ ${ }^{2}$ Balai Riset Budidaya Ikan Hias
}

\section{ABSTRACT \\ Analysis Genetic Variation of Three Strains of Red Tilapia by Anova of RAPD. By. Iskandariah, Otong Zenal Arifin and Rudhy Gustiano}

\begin{abstract}
Study on the genetic variance of three strains of red tilapia (Oreochromis sp) had been conducted in the Biology Molecular Laboratory, Research Institute for Freshwater Aquaculture (RIFA) Bogor. Three different strains, Red NIFI from Thailand, Red Tilapia from Lido lake and Red Tilapia from Bogor's farmer were analyzed in the study. Observation used Random Amplified Polymorphism DNA (RAPD) with OPA-03, OPA-04, OPC 14 and OPC-15 primers. The results showed that only OPA-03 primer was able to amplify numerous samples. Further analysis showed that the percentage of polimorphic range was between $16.67-38.89 \%$, heterozygosity value $0.0378-0.1536$ and genetic distance among strain $0.3051-0.6037$.
\end{abstract}

Keywords : RAPD, genetic, strain, nile tilapia, oreochromis

\section{ABSTRAK}

Penelitian mengenai variasi genetik tiga strain nila merah dari 3 lokasi yang berbeda telah dilakukan di Laboratorium Molekuler Biologi, Balai Riset Perikanan Budidaya Air Tawar (BRPBAT) Bogor. Strain yang diamati meliputi jenis nila Red NIFI dari Thailand, nila merah dari Danau Lido dan nila merah dari Petani Bogor. Penelitian menggunakan metode analisis Random Amplified Polymorphism DNA (RAPD), dengan menggunakan primer OPA-03, OPA-04, OPC-14 dan OPC-15. Hasil pengamatan menunjukkan hanya OPA-03 yang dapat menghasilkan amplifikasi dalam jumlah sampel yang memadai. Hasil analisis menunjukkan bahwa persentase polimorfik berkisar antara 20.00-40.00\%, dengan nilai heterozigositas 0.0604-0.1516 dan jarak genetik antar strain 0.1770-0.4865.

Kata kunci : RAPD, genetik, strain, ikan nila, oreochromis

\section{PENDAHULUAN}

Ikan nila merah merupakan ikan introduksi asal Filipina (1981) dan Thailand (1989). Beberapa keunggulan yang dimiliki seperti mudah berkembang biak, pertumbuhan relatif cepat, tahan terhadap hama penyakit dan toleransi yang cukup luas terhadap perubahan lingkungan menyebabkan teknologi budidaya ikan ini berkembang cukup luas di beberapa daerah di Indonesia bahkan produksinya telah diekspor ke beberapa negara Eropa, Singapura, Jepang dan Amerika Serikat. Selain dapat diekspor dalam bentuk fillet segar juga dapat diekspor dalam keadaan hidup.

Budidaya ikan nila merah dapat dilakukan di kolam, sawah, tambak, keramba, jaring apung, baik diperairan tawar, payau maupun di tepi pantai. Tingginya animo masyarakat dalam membudidayakan ikan nila merah ini berdampak pada perubahan kualitas genetik turunan yang dihasilkan akibat kurangnya pemahaman mengenai pengelolaan induk yang baik. Penurunan kualitas genetik ikan secara umum ditandai dengan sifatsifat seperti pertumbuhan lambat, tingkat kematian tinggi, kematangan gonad pada usia dini dan ukuran individu yang kecil.

Penelitian perbaikan genetik untuk ikan nila hitam telah banyak dilakukan di Indonesia, namun untuk nila merah belum banyak dikaji. Pada penelitian yang dilakukan oleh Nugroho dan Maskur (2002) dengan menggunakan metode mtDNA menunjukkan terdapat indikasi bahwa salah satu induk nila merah adalah berasal dari nila hitam. Menurut Nugroho dan Maskur (2002), beberapa peneliti berpendapat bahwa ikan nila merah merupakan hasil hibrid dari nila hitam dan nila putih/bule, namun demikian hasil riset yang mendukung pendapat tersebut belum ada.

Mengingat peranan ikan nila merah yang cukup strategis bagi perikanan budidaya di Indonesia, maka penelitian dasar yang menunjang untuk perbaikan mutu genetik ikan nila merah penting untuk dilakukan. Tujuan dari penelitian ini adalah untuk mengetahui keragaman genetik ikan 
nila merah yang dikoleksi dari 3 lokasi yang berbeda, yaitu Red NIFI, Merah Lido dan Merah Petani dengan menggunakan metode Random Amplified Polymorphism DNA (RAPD), sebagai informasi dasar dalam meningkatkan mutu genetik ikan nila merah.

\section{BAHAN DAN METODE}

\section{Ikan Uji}

Ikan uji yang digunakan adalah 3 strain ikan nila merah koleksi yang diambil dari lokasi yang berbeda, yaitu Red NIFI dari Thailand ukuran 5-8 cm (10 sampel), nila merah dari Danau Lido ukuran 5-8 cm (10 sampel) dan nila merah dari Petani Bogor ukuran 3-5 cm (10 sampel). Sampel ikan nila yang digunakan berupa sirip yang dipotong dan disimpan dalam larutan alkohol $70 \%$ untuk digunakan dalam proses analisis.

\section{Ekstraksi DNA}

DNA ikan diekstraksi dari potongan sirip dengan menggunakan metode Phenol-Chloroform (Nugroho, 2001). Potongan sirip sebanyak 5-10 mg dimasukkan dalam mikrotube $1,5 \mathrm{ml}$ yang telah diisi dengan $500 \mathrm{ml}$ TNES Urea, kemudian ditambah $10 \mu \mathrm{l}$ protein kinase. Setelah divortex selama 1 menit sampel diinkubasi pada suhu $37^{\circ} \mathrm{C}$ selama 24 jam. Selanjutnya ditambah larutan Phenol Chloroform sebanyak $1000 \mu \mathrm{l}$ dan divortex selama 1 menit. Sampel kemudian disentrifius dengan kecepatan $10.000 \mathrm{rpm}$ selama 10 menit. Supernatan diambil dan dimasukkan dalam mikrotube baru, lalu ditambah dengan $1000 \mu \mathrm{l}$ ethanol $90 \%$ dan $10 \mu \mathrm{CH}_{3} \mathrm{COONa}$. Sampel lalu divortex selama 1 menit sampai terlihat gumpalan berwarna putih. DNA diendapkan dengan cara mensentrifiusnya dengan kecepatan 10.000 rpm selama 10 menit, lalu dikeringkan pada suhu kamar. Pelet DNA dilarutkan dengan $100 \mu \mathrm{l}$ Tris-EDTA (TE) buffer dan disimpan pada suhu $4{ }^{\circ} \mathrm{C}$ sebelum digunakan pada tahap selanjutnya.

\section{Random Amplified Polymorphism DNA (RAPD)}

Primer yang digunakan adalah OPA-03 dengan urutan basa AGT CAG CCA C. Proses amplifikasi dilakukan dengan metode Polymerize Chain Reaction (PCR) dengan komposisi reaksi: $1 \mu 1$ DNA, $1.5 \mu$ l primer, $12.5 \mu 1$ 2X PCR Master Mix dan $10 \mu \mathrm{l} \mathrm{H}_{2} \mathrm{O}$; dengan total volume $25 \mu \mathrm{l}$. Selanjutnya dimasukkan dalam thermocycler dengan 1 siklus denaturasi pada suhu $94{ }^{\circ} \mathrm{C}$ selama
2 menit, 35 siklus penggandaan yang terdiri dari denaturasi pada suhu $94{ }^{\circ} \mathrm{C}$ selama 1 menit, annealing pada suhu $36{ }^{\circ} \mathrm{C}$ selama 1 menit dan elongasi pada suhu $72{ }^{\circ} \mathrm{C}$ selama 2,5 menit; dan elongasi akhir pada suhu $72{ }^{\circ} \mathrm{C}$ selama 7 menit. Hasil PCR kemudian dielektroforesis menggunakan gel agarose $1 \%$ dalam Tris-Boric-EDTA (TBE) buffer $1 \%$. Hasilnya diamati dengan UV illuminator dan dicetak gambarnya dengan Polaroid.

\section{Analisis Data}

Analisis data menggunakan software Tools For Population Genetic Analysis (TFPGA). Variasi genetik antar populasi menggunakan Analysis Moleculer of Varians (AMOVA) dan Fst, sedangkan kekerabatan antar populasi menggunakan jarak genetik (D) yang dianalisis berdasarkan Wright (1978) modifikasi Rogers (1972).

\section{HASIL DAN PEMBAHASAN}

Dari 4 jenis primer yang dicoba, yakni : OPA-03, OPA-04, OPC-14 dan OPC-15, hanya OPA-03 yang dapat menghasilkan amplifikasi dalam jumlah sampel yang banyak. Jumlah fragmen yang dihasilkan melalui analisa menggunakan pimer OPA-03 sebanyak 8 sampai 11 fragmen, dengan ukuran fragmen berkisar antara 200 sampai 1600 bp dan jumlah lokus sebanyak 15 lokus. Hasil amplifikasi primer OPA-03 pada strain nila Red NIFI disajikan pada Gambar 1, sedangkan strain nila merah Danau Lido pada Gambar 2 dan strain nila merah petani pada Gambar 3.

Secara umum keragaman genetik ikan nila merah yang diuji relatif rendah dengan kisaran nilai polimorfisme $20.00-40.00 \%$ dan heterozigositas 0.0604-0.1516 (Tabel 1). Hasil yang sama juga terjadi pada penelitian Iskandariah et al. (2009), lima strain ikan nila yang diuji meliputi ikan nila merah Danau Lido, Red NIFI, nila lokal Kuningan, nila lokal Bogor dan nila BEST memiliki persentase polimorfisme berkisar antara $22.22-38.89 \%$ dan heterozigositas $0.0378-0.1536$. Rendahnya tingkat keragaman genetik ini disebabkan karena ikan air tawar mempunyai tingkat migrasi yang lebih rendah sehingga peluang terjadinya persilangan dengan jenis dan ras lainnya juga semakin kecil (Kirpichnikov, 1981; Tave, 1991).

Analisis statistik dengan menggunakan AMOVA menunjukkan bahwa terdapat perbedaan genetik secara nyata antara strain nila Red NIFI dengan nila merah Danau Lido dan nila merah Petani $(\mathrm{P}<0.05)$, sedangkan antara nila merah 
Danau Lido dan nila merah Petani tidak terdapat perbedaan yang nyata $(\mathrm{P}>0.05)$. Hal ini disebabkan karena antara strain nila merah Danau Lido dan nila merah Petani kemungkinan mempunyai hubungan kekerabatan berdasarkan strain yang pernah di datangkan ke Indonesia, sedangkan nila Red NIFI yang digunakan merupakan ikan introduksi baru. Hasil analisa statistik ditampilkan pada Tabel 2.

Jarak genetik tertinggi antara strain nila merah Red NIFI dan nila merah Petani dan terendah antara nila merah Danau Lido dengan nila merah petani (Tabel 3). Dendogram yang dibentuk berdasarkan jarak genetik tersebut menunjukkan bahwa antara strain nila merah Danau Lido dan nila merah Petani terdapat hubungan kekerabatan yang lebih dekat, dibandingkan dengan hubungan kekerabatan antara strain nila Red NIFI dan 2 strain lainnya (Gambar 2). Kedekatan hubungan kekerabatan antara strain nila merah Danau Lido dan nila merah Petani disebabkan karena keduanya mempunyai asal-usul induk yang relatif sama, sementara nila Red NIFI merupakan generasi terbaru dari Thailand. Keadaan serupa juga terjadi pada ikan kingfish yang dikoleksi Jepang, Australia dan New Zealand (Nugroho et al., 2001).

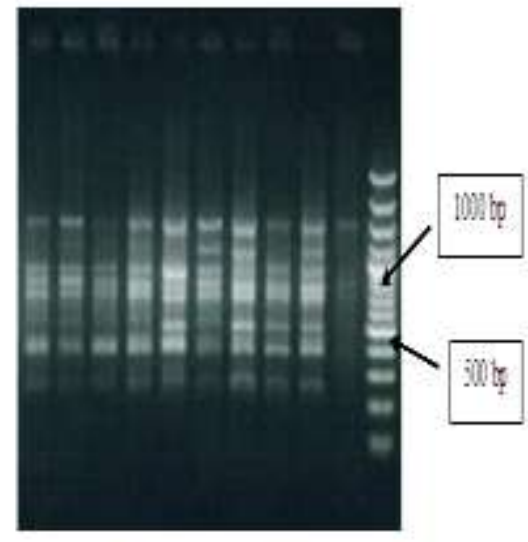

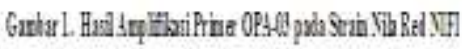

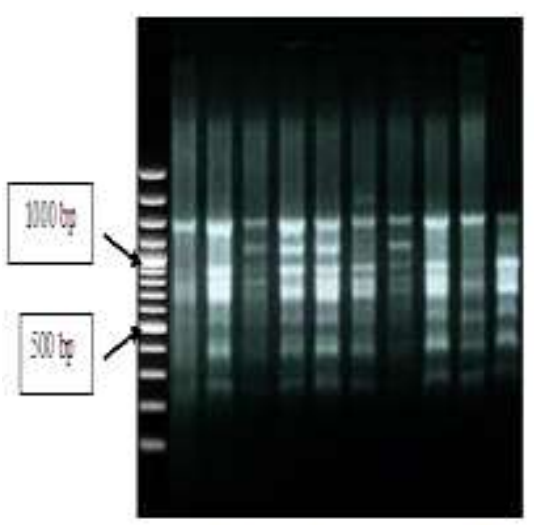

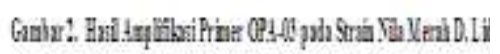

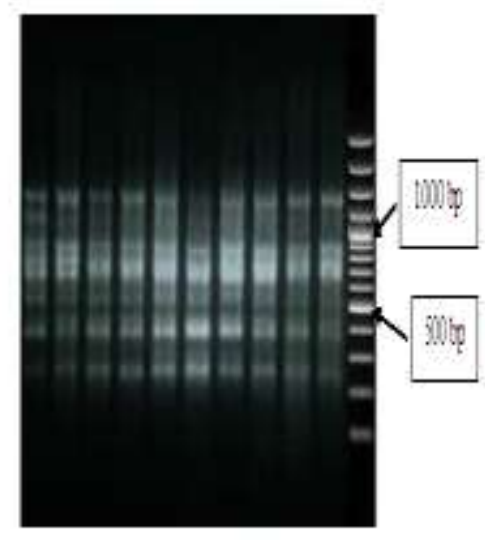

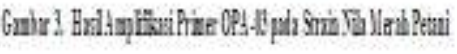

Tabel 1. Nilai Polimorfisme dan Heterozigositas Tiga Strain Nila Merah Menggunakan Primer OPA-03

\begin{tabular}{lllll}
\hline \multirow{2}{*}{ No. } & Keterangan & Strain & & \\
\cline { 3 - 5 } & & Red NIFI & Nila Merah D.Lido & Nila Merah Petani \\
\hline 1. & Polimorfisme & $40.0000 \%$ & $26.6667 \%$ & $20.0000 \%$ \\
2. & Heterozigositas & 0.1516 & 0.0926 & 0.0604 \\
\hline
\end{tabular}

Tabel 2. Hasil Uji Fst Berpasangan Tiga Strain Nila Merah Menggunakan Primer OPA-03

\begin{tabular}{llll}
\hline Strain & Red NIFI & Nila Merah D. Lido & Nila Merah Petani \\
\hline Red NIFI & $* * * *$ & & \\
Nila Merah D. Lido & 0.0000 & $* * * *$ & \\
Merah Petani & 0.0000 & 0.9140 & $* * * *$ \\
\hline
\end{tabular}

Tabel 3. Jarak Genetik antar 3 Populasi Nila Merah dengan Primer OPA-03

\begin{tabular}{llll}
\hline Strain & Red NIFI & Nila Merah D. Lido & Nila Merah Petani \\
\hline Red NIFI & $* * * *$ & & \\
Nila Merah D. Lido & 0.4195 & $* * * *$ & \\
Merah Petani & 0.4865 & 0.1770 & $* * * *$ \\
\hline
\end{tabular}



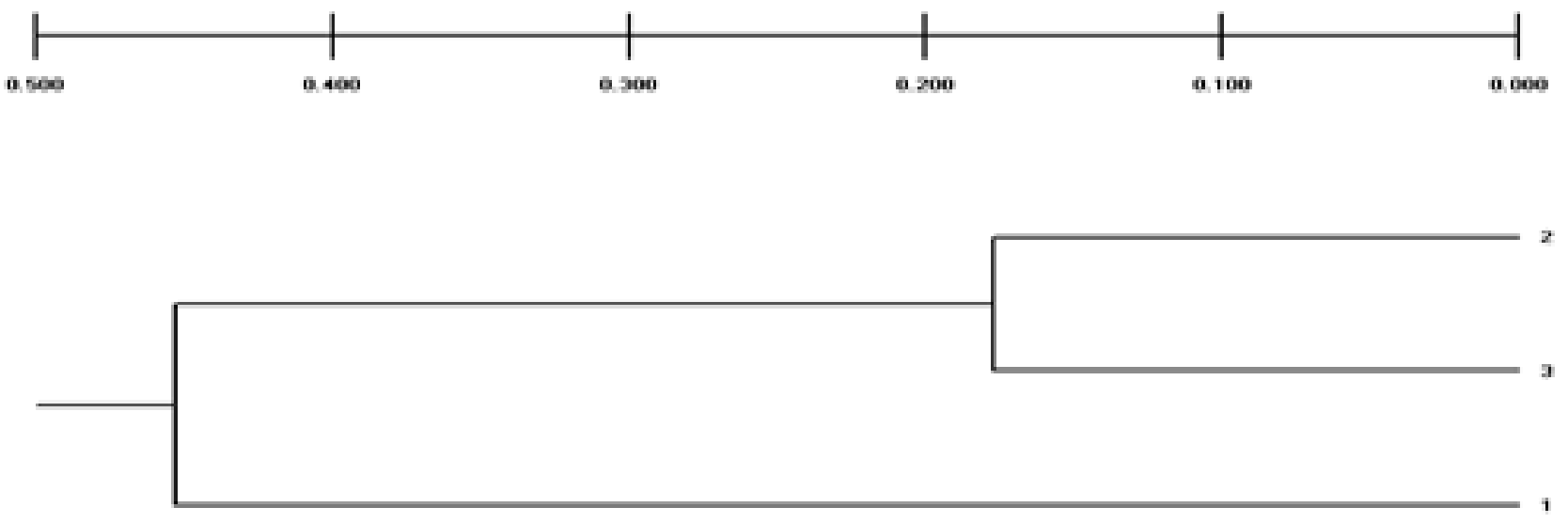

Gambar 4. Dendogram dari 3 Strain Nila Merah yang Diamati.

1= Red NIFI; 2= Nila Merah Danau Lido; 3= Nila Merah Petani

\section{KESIMPULAN}

Strain nila Red NIFI, nila Merah Danau Lido dan nila Merah Petani mempunyai tingkat keragaman genetik yang rendah dengan kisaran polimorfisme $20.00-40.00 \%$ dan heterozigositas antara 0.0604-0.1516. Terdapat perbedaan genetik secara nyata antara strain ikan nila merah Red NIFI dengan nila Merah Lido dan Merah Petani, sedangkan antara nila Merah Lido dan Merah Petani tidak terdapat perbedaan yang nyata. Jarak genetik tertinggi antara strain nila merah Red NIFI dan Merah Petani dan terendah antara nila Merah Lido dengan Merah petani.

\section{UCAPAN TERIMA KASIH}

Penulis mengucapkan terima kasih kepada Balai Riset Perikanan Budidaya Air Tawar. Penelitian ini merupakan bagian penelitian perikanan budidaya air tawar yang dibiayai oleh DIPA TA 2009.

\section{DAFTAR PUSTAKA}

Iskandariah, I. I. Kusmini, O. Z. Arifin dan R. Gustiano. 2009. Variasi genetik 5 populasi ikan nila (Oreochromis niloticus) dengan metode analisis Random Amplified Polymorphism DNA (RAPD). Seminar nasional perikanan Indonesia 2009. Sekolah Tinggi Perikanan, Jakarta.

Kirpichnikov, V. S. 1981. Genetic based of fish selection. 410 pp. Springer-Verlag,

Berlin, Heidelberg, Germany.
Miller, M. P. 1997. Tools For Population Genetic Analysis (TFPGA) version 1. 3. Department of Biological Science. Northern Arizona University, Arizona, USA, 30 pp.

Nugroho, E. 2001. Capability of mitochondria DNA D-Loop markers from shark species identification. Indonesian Fisheries Research Journal, 7(1): 62-66.

Nugroho, E., D. J. Ferrell, P. Smith and N. Taniguchi. 2001. Genetic divergence of kingfish from Japan, Australia and New Zealand inferred by microsatellite DNA and mitochondrial DNA control region markers. J. Fisheries Science, $67: 843-850$.

Nugroho, E dan Maskur. 2002. Benarkah ikan nila merah adalah hasil hybrid? (melacak asal usul nila merah dengan menggunakan molecular genetic markers). Warta penelitian perikanan Indonesia, Vol. 8 No. $1: 8-11$.

Tave, D. 1993. Genetics for fish managers. The AVI Publ. Comp. Inc. NY, USA, 418 pp.

Wright, 1978. Modifikasi Rogers 1972. Analysis Moleculer of Varians (AMOVA) dan Fst, sedangkan kekerabatan antar populasi menggunakan jarak genetik (D) yang dianalisis. 